\title{
A bela ordem incorpórea no Filebo de Platão
}

\author{
Rodolfo Rachid ${ }^{1}$
}

RESUMO: Neste artigo, pretendo analisar como o Filebo de Platão retoma alguns tópicos específicos da dialética platônica, empregando-os a fim de entender como a alma cognitiva pode ser afetada por prazeres falsos, por opiniôes falsas e por imagens falsas. Este estudo visa a criticar certas leituras modernas do platonismo, especialmente a teoria esoterista, baseada na doutrina não escrita de Platão, cujo escopo central estipula um revisionismo da teoria platônica das Formas, defendendo a emergência de uma nova ontologia, explicada por dois princípios, o Um e a Díada ilimitada do grande e do pequeno, concebidos, assim, como princípio formal e princípio material.

PALAVRAS-CHAVE: Dialética. Ontologia. Ideia do Bem. Ética eudemonista. Prazeres falsos. Imitação sábia.

Se, nos diálogos platônicos predecessores ao Filebo, o problema da relação entre o um e o múltiplo, estratégico para a filosofia pré-socrática e platônica e evidenciado nos Diálogos, na relação entre a ideia e a pluralidade fenomenal, entre a forma única e a multiplicidade aparente, é pensado em termos ontológicos ou de participação no Fédon ou de semelhança na República ou então de comunidade no Sofista, no Filebo, diálogo sobre o prazer e a vida feliz, será pensado em termos da mistura entre elementos antitéticos, o limite e o ilimitado. A oposição entre finito e infinito, entre uma natureza definida e limitada e outra indefinida e ilimitada não é uma questáo apenas pitagórica, mas pode ser aferida tanto na física milésia, no entorno da concepção anaximandreana de ilimitado, de onde provêm os congêneres, quanto na cosmologia parmenídica, adstrita à definição de ser como esfera

\footnotetext{
${ }^{1}$ Doutor em Letras Clássicas pela Universidade de São Paulo. Endeço eletrônico: rodolforachid@uol. com.br
} 
delimitada e perfectiva. A discussão sobre a natureza do prazer proposta no Filebo reitera, em nova chave, a problemática eleata da concentração no um e consequente dispersão fenomênica na multiplicidade aparente, escrutinada no Sofista por meio da comunidade dos gêneros.

A leitura e interpretação dos Diálogos apenas pelo prisma pitagórico reduz a possibilidade de interpretá-lo por meio de uma incessante comunicação da obra platônica com as proposituras eleatas, fundamento da invectiva socrática à antilogia erística, atestada no proêmio do Filebo relativa à alusão ao Palamedes eleata. A tradiçấo comentativa que analisa esse diálogo final pelo prisma eminentemente pitagórico e matematístico esmaece os nexos entre o platonismo e o pensamento eleático e sua crítica ao mau discurso. Por intermédio da leitura de Monique Dixsaut (DIXSAUT, 2001, p. 286), “[...] o Filebo é o terreno da eleição dos defensores de uma nova ontologia de Platão e dos partidários das ágrapha dógmata, doutrinas não escritas", pois exprimiria, para esses autores, como Konrad Gaiser, Hans Krämer e Thomas Alexander Szlezák, suas preocupaçóes finais partilhadas por seus discípulos na Academia e registradas pela doxografia aristotélica, circunscritas à teoria dos dois princípios, formal e material, correlatos ao um e à díada indefinida do grande e pequeno. Para os teóricos do testamento ágrafo, Platão, “[...] rompendo definitivamente não apenas com a hipótese das Formas, mas também com os gêneros supremos do Sofista, operaria naquele diálogo uma revisão minudente de sua ontologia e de seu método, a dialética” (DIXSAUT, 2001, p. 286). Para os partidários da dogmática não escrita que têm, para a autora Monique Dixsaut, a divina surpresa de aferir escritos os dois princípios que, por essa doutrina, seriam a mônada e a díada indefinida do grande e do pequeno, assegurando a existência de realidades matemáticas intermediárias, tratar-se-ia não de uma evolução da dialética platônica, mas da emergência de uma original teoria esoterista. A tese da mescla comum entre prazer e sabedoria, assegurando a vida média feliz, revelar-se-ia, para a interpretaçáo esoterista, apenas "[...] o pretexto permitindo a Platão expor seus novos princípios metodológicos ou os seus princípios ontológicos ocultos" (DIXSAUT, 2001, p. 287).

Por essa perspectiva analítica, esmaecem-se, no platonismo tardio, o componente ético político e os tópicos reiterantes da dialética platônica, como (i) a crítica à erística, (ii) a invectiva das paixóes deletérias, (iii) o opróbio à má escrita, (iv) a asserção de que a gênese do esquecimento é a fuga da memória, (v) a prática da alma remêmora, (vi) a analogia entre as artes dialética, gramática e musical, em favor, portanto, de uma dogmática ágrafa, que anula tanto o 
âmbito cultual relativo à hermenêutica platônica de herança mítica, quanto o político, correlato ao entendimento da relação do filósofo com outros gêneros produtores de discursos existentes na pólis ateniense clássica, como o retor, o poeta e o sofista. Se lêssemos Platão por um sistema apriorista de princípios em torno do um, considerado princípio formal, e da díada indefinida do grande e do pequeno, considerada princípio material, correlatos ao limite e ao ilimitado, reconheceríamos iniludivelmente nele antinomias e lacunas. $O$ Filebo, assim como a maioria dos diálogos platônicos, pertence prevalentemente ao gênero ético, que, desde o Mênon, diálogo intermediário, de acordo com o estudo de Harold Cherniss (2004) sobre a economia filosófica da teoria platônica das Formas, contempla, também, a ontologia.

Pretendo mostrar como, pela discussáo sobre a gênese efetiva dos prazeres realizada no Filebo, se reiteram os lugares comuns da dialética filosófica platônica, atestada tanto em diálogos intermediários como República e Fedro quanto em diálogos finais, como Sofista e Político, de modo que me oponho à leitura esoterista que pensa o Filebo como uma reavaliação da teoria platônica das Formas, apoiando-se, para tanto, no escrutínio de seu testamento ágrafo, isto é, de seu testemunho não escrito, partilhado por seus discípulos na Academia. Julgo relevante pensar o Filebo de acordo com os tópicos supracitados, constituintes da dialética filosófica atestada nos Diálogos e não pela teoria dos dois princípios proposta pela leitura esoterista. A compreensão da dialética filosófica como ciência discricionária dos gêneros é observada tanto no Sofista quanto no Filebo, pois, "[...] assim como o excurso sobre os mégista gene do Sofista fornece os critérios para explicar o náo ser e a falsidade, no Filebo o excurso sobre os quatro gêneros da vida feliz busca explicar a estrutura da realidade para dar conta da natureza da razão e do prazer" (MIÉ, 2004 [2]).

A ética mnemônica, propugnada no diálogo por um Sócrates habilidoso na ciência dialética, prescreve ser a sabedoria e a memória os bens absolutos para a vida feliz (bios eudaimon). A ética hedonista, ao contrário, prescreve ser o prazer o bem absoluto. Qual é a vida feliz (bios eudaimon)? Duas teses são expostas; a primeira, defendida por Filebo, define ser o prazer (hedonè), enquanto a segunda, defendida por Sócrates e antitética àquela, define ser a sabedoria (phronèsis). Filebo afirma ser bom (agathòn) para todos os viventes a graça (tò chaírein), o prazer (tèn hedonèn), o júbilo (térpsin) e tantas quantas consoantes a esse gênero (Fil. 11b3). Sócrates argumenta não ser aquelas, mas antes o conhecer (tò phroneîn), o pensar (tò noeîn) e o rememorar (memnesthai) e todos os congêneres, já que a reta opinião (dóxan orthèn) e o raciocínio 
verdadeiro (aletheîs logismoûs) são melhores que o prazer (tês hedonês) (Fil. 11c). A reta opiniáo associada ao raciocínio da causa, portanto, verdadeiro, nos remete ao estabelecimento da ciência no Mênon. Sócrates destaca a importância de evidenciar uma disposição e condição da alma (héxin psychês kai diáthesin) que assegure a todos os homens a possibilidade de uma vida feliz (tòn bion eudaimona), argumentando ser a vida do conhecer, enquanto Filebo declara ser a vida da graça (Fil. 11d), entendida em seu sentido hedonista. Se o prazer dominasse a intelecção, haveria o poder da vida hedonista (krateî bios tês hedonês) e, se houvesse o inverso, adviria o poder da vida sábia (tês phronéseos) (Fil. 12a). Sócrates refletira sobre o prazer e a sabedoria, concluindo que nenhum deles seria o Bem, mas seria um terceiro, diferente e melhor que ambos. O Filebo retoma a conspícua concepção da forma do Bem, analisada em República VI. A forma do Bem, ideia supraessencial, atestada em República VI, ao mesmo tempo em que assegura no Filebo os critérios dianoéticos de medida, proporção e beleza, é por eles pensada. A classe do Bem é considerada a mais perfeita e suficiente, diferindo-se de todos os entes. Sócrates rejeita que todos os prazeres sejam bons, haja vista que Protarco afirma ser o prazer um bem (tagathón) (Fil. 13b). A tese de Protarco institui prazeres bons e maus como idênticos e semelhantes, não diferenciando as múltiplas espécies em um gênero único e o mesmo, sendo preciso, pelo método de divisão por formas, discerni-los. Se o método diairético institui no Sofista os mégista gène, estabelece no Filebo a bela ordem incorpórea entre os quatro gêneros da vida mista feliz. Se há prazeres maus, eles são mutuamente dessemelhantes (anomoious allélais) e contrários (enantías) aos prazeres bons, não podendo ser todos idênticos ao mesmo gênero do Bem. Protarco, não diferenciando as espécies de prazer, não compreende a multiplicidade determinada, confundindo coisas semelhantes e dessemelhantes, iguais e desiguais, operação própria ao erístico.

Como rejeitar o peremptório componente moral e político presente na indagação socrática sobre a relação entre a forma única e a pluralidade? Segundo Sócrates, todas as ciências parecem ser múltiplas e reciprocamente dessemelhantes. No processo de oposiçóes, em que o um devém múltiplo, existe uma natureza admirável, concebida como o um (tó hén), não sendo, todavia, estabelecido por aqueles que devêm e se corrompem (tôn gignoménôn te kaì apolluménon) (Fil. 15a). O um é sempre idêntico a si próprio, ingênito e incorruptível. $\mathrm{O}$ entendimento socrático da relação entre o um e o múltiplo opor-se-á à concepção da erística, concernente a Zenão de Eleia, acerca da impossibilidade da multiplicidade, porquanto, para ele, é inconsistente anuir a existência do múltiplo, pois se os entes fossem múltiplos, náo poderiam, 
ao mesmo tempo, ser semelhantes e dessemelhantes, nem o semelhante devir dessemelhante e reciprocamente. Se há a multiplicidade, é preciso admitir a natureza do devir, concomitante à aceitação da essência. O equívoco de Zenão reside no desconhecimento das relaçóes efetuadas entre ideia e pluralidade fenomênica, entre o um, entendido como essência, e a multiplicidade aparente. Sócrates intenta examinar a natureza do um e do múltiplo, recusando uma provável identidade entre eles, porque é preciso admitir se tais unidades realmente existem (monádas alethôs oúsas) e como cada uma, sendo sempre a mesma e não aceitando nem geração nem destruição (méte génesin méte ólethron), pode ser em sua totalidade uma unidade a mais estável. Assim, deve-se instituir naqueles que devêm (en toîs gignoménois) e nos infinitos (apeírois) ou como sendo múltiplos e dispersos ou, o que parece ser de todas as coisas a mais implausível (adynatótaton), como sendo idênticos e unos que, separando-se, devêm, concomitante, no um e na pluralidade (Fil. 15b). Não se pode aceitar a indistinção entre o plano fenomênico e o plano numênico, erro praticado pela arte erística. O mito primacial de Prometeu exprime, segundo o relato socrático, a relação entre o um e a multiplicidade aparente, unindo discurso filosófico e discurso mitopoético. O fogo ofertado pelos deuses para que Prometeu conceda aos mortais se liga às liçôes e ensinamentos indispensáveis relatados pelas antigas tradições, pois os antigos, morando perto dos deuses, deram a fama de que, do um e do múltiplo, os entes existem sempre, contendo o limite (péras) e o ilimitado (apeirían) ${ }^{2}$ neles próprios e brotados conjuntamente (Fil. 16c).

Mas, deve-se instituir uma forma única (mían idéan) para cada ente que se examine, visto que as coisas se ordenam no todo. A diacosmese nasce precisamente da relação entre o um e a dispersão fenomenal. O um não se

2 Para Mié, no Filebo, um Sócrates experiente nas artes dialéticas está em condiçốes de resolver o problema, do qual se ocupava o Sócrates jovem do Parmênides, correlato ao logos de que o um é múltiplo e ilimitado e o múltiplo é um. Cf. MIÉ (MIÉ, 2004 [2], p. 234): "En el Filebo, um Sócrates maduro en las artes dialécticas está en condiciones de asumir el problema ante el que se detenía el joven Sócrates del Parménides; así, Sócrates expresa, en el primero de estos diálogos, que es preciso admitir aquella maravillosa (thaumastón, Phlb. 14 c 8; cf. Prm. 129 e 4 thaumastôs) tesis (logos Phlb. 14 c 1), según la cual lo uno es múltiple e ilimitado y lo múltiple es uno (Phlb. 14 e 3-5)”. Huffman (HUFFMAN, 1999, p. 17) investiga as origens das noçóes do limite e do ilimitado, rejeitando a tese de Charles H. Kahn, para quem o Ápeiron seria, antes, registrado na física milésia de Anaximandro. Huffman anui que os princípios do limite e do ilimitado são atestados nas teorias de Anaxágoras e Zenão na segunda metade do V o século. Segundo Huffman, “[...] Filolau não se refere aos princípios abstratos como o princípio do limite e o do ilimitado, expostos por Platão no diálogo Filebo (péras, apeirian), mas fala no plural de limitantes e ilimitados". Cf. DIXSAUT (2001, p. 298): "Carl Huffman a brillamment demontré que rien chez Platon ne suggère que le système de la limite et de l'illimité remonte jusqu'à Pythagore". 
altera na gênese, porque mesmo no devir o um se mantém sempre idêntico a si mesmo, não admitindo em si os contrários, sendo próprio do método erístico não diferir o um da pluralidade fenomênica, não reconhecendo entre eles seus intermediários. Cada ente possui sua forma, sendo essa forma conhecida pelo citado método de divisão. "Platão parece-nos insinuar que o um, o gênero, em si mesmo, é múltiplo, pois o gênero contêm as diferenças que constituem as espécies, o que é coerente com a teoria das ideias" (PATER, 1965, p. 51). Cada etapa do método de divisão possui dois gêneros ou espécies, ou um limitado número possível, uma vez que o que é visado se insere em determinado gênero pela exclusão de seu pertencimento a outro. No que concerne à forma do infinito não é certo relacioná-la ao múltiplo sem considerar o seu número total no intervalo entre o infinito e o um (Fil. 16d). Os deuses (hoi theoi) nos ofertaram reciprocamente, profere Sócrates, examinar, aprender e ensinar (skopeîn kaì manthánein kaì didáskein) (Fil. 16e). Os homens sábios coetâneos, pondo lepidamente os infinitos depois do um, ignoram seus intermediários, porquanto respeitá-los é o que diferencia o dialético do erístico, o filósofo dos muitos produtores de discursos.

Sócrates busca precisar a relação entre o um e o infinito pelo modelo do alfabeto. $\mathrm{O}$ entrelaçamento entre vogais e consoantes produz uma originária estrutura mental que revoluciona as categorias de pensamento gregas, já que, entendido o ilimitado dos sons, quer por um deus, quer por um homem divino, uma tradição egípcia revelou que Theuth foi o primeiro a entender que, no infinito, as vogais não são o um, mas múltiplas, com semivogais, dispondo também uma terceira espécie de letras, as consoantes, denominando-as elementos. Os elementos formam um liame único, revelado pela arte gramatical, "[...] liame de interdependência, servindo de exemplo para cada arte determinada" (GADAMER, 1994, p. 83). Para Dixsaut (DIXSAUT, 2001, p. 304), o dialético possui um problema análogo ao de Theuth, o inventor do alfabeto fonético, pois se trata de produzir, a partir de uma realidade ilimitada, um conjunto organizado de elementos interdependentes. $\mathrm{O}$ recurso ao alfabeto e à sua arte adequada, a gramatical, evidencia, no âmbito sensível, a comunidade ontológica dos gêneros supremos e sua ciência, a dialética. $O$ paradigma do alfabeto auxilia no reconhecimento das presumíveis espécies de prazer e sabedoria, ajudando-nos a discernir no todo complexo suas formas próprias. $\mathrm{O}$ exemplo egípcio exprime o ato do pensamento em face do indeterminado, haja vista que, por meio da dialética, a multiplicidade indefinida se tornaria pluralidade determinada, reconhecida, por exemplo, na música e na gramática. Para Dixsaut (DIXSAUT, 2001, p. 312), o ilimitado não é uma matéria que o limite informaria, mas um 
devir estabilizado pelo limite, um perpétuo desigual em si, processo que não se pode reconhecer nem princípio, nem meio, nem fim, rejeitando a correlação esoterista dos princípios ontológicos do limite e do ilimitado ao um, causa formal, e à díada indefinida do grande e do pequeno, causa material. A análise dos prazeres permite efetuar a operação dialética supracitada, discriminando no gênero do prazer suas múltiplas espécies. Filebo, partidário da vida hedonista, de um lado, aquiesce ser o prazer, o júbilo, a graça e congêneres o melhor dentre os bens humanos. Sócrates, de outro, sustenta ser a rememoração, porquanto as reminiscências em nossa memória precisam ser convenientemente julgadas. O bem laudável, considerado melhor do que o prazer, seria, para Sócrates, o intelecto, a ciência, a compreensão (sýnesin), a arte e seus cognatos (Fil. 19c). Sócrates procede à investigação e julgamento da vida hedonista (tón hedonês bion) e da vida sábia (tòn phronéseos bion), considerando-as separadamente, não havendo sabedoria na vida hedonista nem tampouco prazer na vida sábia, pois, se uma delas, a vida sábia ou a vida hedonista, fosse o Bem, não careceria de nada, sendo, ao mesmo tempo, tanto autônoma quanto autárquica. A autonomia e a autarquia se referem apenas à ideia e poder supraessencial do Bem, ideia que supera as outras ideias em poder e majestade. Mas, se precisasse de algo, não seria o Bem real (tò óntos agathón). Sócrates, a fim de investigar dialeticamente a real natureza autárquica do Bem, sugere a Protarco viver toda a vida, aprazendo-se (hedómenos) dos maiores prazeres (hedonàs tás megistas), de forma que, tendo-os inteiramente (pantelôs), não careceria de nada, nem do conhecer (tôu phroneîn), nem do pensar (tôิ noeîn), nem do raciocinar (logidzesthai) (Fil. 21a). Protarco admite não precisar de nada, vivendo a plenitude da vida hedonista.

A tese de Protarco defende a prevalência do hedonismo, rejeitando qualquer outro bem. Porém, se náo possuísse o intelecto (nồn), a memória (mnémen), a ciência (epistémen) e a opinião verdadeira (dóxan alethê), seria preciso, primeiramente, ignorar, sendo vazio de toda sabedoria (kenón páses phronéseos), se se apraz ou não (Fil. 21b). Do mesmo modo, sendo privado de memória, não poderia relembrar se um dia regozijara, não remanescendo nenhuma memória do prazer experimentado no instante atual (Fil. 21c). Da mesma forma, ausentando-lhe a opiniâo verdadeira, não lhe pareceria regozijar, mesmo regozijando, e carecendo-lhe, decerto, o raciocínio, náo conseguiria calcular os prazeres porvindouros, não vivendo uma vida humana, não havendo, quer na vida hedonista quer na vida sábia, nem autonomia tampouco autarquia. A ética hedonista, prescrevendo o prazer, o júbilo e a graça como bens hegemônicos, necessitaria, para poder vivê-los plenamente, dos bens propriamente intelectuais e dianoéticos, o conhecer, o raciocinar, a 
memória, a opiniấo verdadeira e raciocínio. Sócrates permanece respeitoso ao culto de Afrodite, reconhecendo-a como um membro da família dos deuses olímpios, limitando a pretensão de impô-la como o único poder regente do mundo (GADAMER, 1994, p. 95). A ética hedonista não é uma ética da compleição, ausentando-lha o elemento dianoético. Recusar uma vida inteiramente hedonista não acarretaria na aceitação de uma vida inteiramente sábia, pois se aceitássemos viver, possuindo, em sua totalidade, sabedoria, inteligência, ciência e memória, não participando nem de um grande prazer tampouco de um pequeno, náo havendo a dor, viveríamos em inteira apatia, não sendo uma vida digna de escolha. As teses antitéticas, opondo as vidas hedonista e sábia, não respondem sobre a real natureza do Bem.

Aduzindo que o bem náo estaria em nenhuma dessas duas vidas, Sócrates propóe que as duas conjuntamente, tendo se misturado, nasceria de ambas uma comum, composta de prazer, intelecto e sabedoria, sendo suficiente, perfeita e digna de escolha para todos os viventes, podendo vivê-la plenamente por toda a vida. Se alguém, porventura, escolhesse outra vida, apreendê-la-ia contrariamente à real natureza do verdadeiramente eleito, compelido involuntariamente pela ignorância ou por uma infeliz necessidade. Parece a Sócrates que não se deve considerar a deusa de Filebo, Afrodite, como idêntica ao Bem, considerado autárquico e autônomo, tampouco parece a Filebo ser meramente o intelecto. O intelecto, para Sócrates, é ao mesmo tempo verdadeiro e divino (alethinòn háma kaì theîon), sendo diferente do prazer. Os prêmios da vitória da vida mista comum, a qual reúne sabedoria e prazer, não são dados apenas ao intelecto, mas também são partilhados pelo prazer. Sócrates defende energicamente que nessa vida mista de prazer e sabedoria, o que a torna ao mesmo tempo eleita e boa (hairetòs háma kai agathós) não é o prazer, mas o intelecto, sendo-lha mais congênere e mais semelhante. Parece ser preciso outro engenho que assegure ao intelecto o segundo lugar.

Sócrates institui o método de divisão por gêneros. $\mathrm{O}$ deus lhe revelara que há nos entes o ilimitado e o limite e das duas espécies deviria a terceira, misturada de ambas. Não obstante, parece a Sócrates ser necessário o quarto gênero, considerado a causa da mistura recíproca daquelas. Sócrates declara, em primeiro lugar, o ilimitado (ápeiron), em segundo lugar, o limite (péras), em terceiro, a essência misturada e nascida (meiktèn kaì gegeneménen ousian) daqueles e, em quarto, a causa da mistura e da geração (tèn tês meíxeos aitían kaì genéseos) (Fil. 27b). Os prêmios da vitória da vida comum e feliz foram atribuidos à vida composta de prazer e sabedoria (tòn meiktòn bion hedonês te kai 
phronéseos), sendo considerada uma parcela do terceiro gênero, não meramente composto desses dois, mas de todos os ilimitados conjuntamente ligados pelo limite. O terceiro gênero seria entendido por Sócrates como um compósito do limite e do ilimitado, e a vida mista de prazer e sabedoria seria concebida como parte do terceiro gênero. Os gêneros da vida mista seriam o limite, o ilimitado, a vida comum e o gênero da causa, que, pela universal e multifária sabedoria, nos concederia a alma, engendraria os exercícios do corpo e a medicina do corpo enfermo, pois há na composição do todo muito ilimitado, suficiente limite e uma causa não insignificante sobre eles, ordenando e governando os anos, os meses e as estaçôes, chamada meritoriamente saber e intelecto, não podendo haver saber e intelecto sem alma. Poder-se-ia mesmo afirmar que é inata à natureza de Zeus, intelecto puro imiscido, uma alma real e um intelecto real (basilikèn psychén te kaì basilikòn noûn), por causa do poder da causa (dià tèn tês aitías dýnamin), havendo outros belos dons nos outros deuses, de acordo com a denominaçáo própria de cada um, sendo declarado pelos antigos, Anaxágoras iniludivelmente, que o intelecto comanda sempre o todo (Fil. 30d). O intelecto é o rei e o poder hegemônico do terceiro gênero, misto do limite e do ilimitado. O enunciado socrático reitera e minudencia a prévia crítica, relativa à segunda navegação, à concepção anaxagorea de intelecto.

Qual é o gênero do intelecto e que poder possui? O intelecto é do gênero denominado causa universal, sendo congênere da causa e próximo a esse gênero, enquanto o prazer é ilimitado em si mesmo, próximo ao gênero que não tem e jamais terá nem princípio, nem meio, nem fim. $\mathrm{O}$ prazer deve ser julgado não separado da dor, pois ambos possuem a mesma gênese, parecendo pertencerem a um mesmo gênero comum, segundo a natureza. Da harmonia se dissolvendo nos viventes surgem a dissoluçáo da natureza e a gênese do sofrimento físico. Porém, harmonizando-se, a saúde dos viventes retorna à sua própria natureza, produzindo o prazer. A fome é dissolução e dor enquanto o alimento e a repleção engendram o prazer. A sede é, ao mesmo tempo, corrupção, dissolução e dor, enquanto o poder do úmido, tendo preenchido o que foi dessecado, é prazer. A separação e a dissolução contra a natureza pelo aquecimento propiciam a dor, enquanto a retribuição e o resfriamento produzem o prazer. $\mathrm{O}$ frio, agindo contra a natureza úmida do vivente, acarretando o congelamento, produz a dor. Porém, o frio, retornando e separando-se em seus elementos primitivos, carreia o prazer. Quando a forma animada nascida naturalmente do limite e do ilimitado se corrompe, a corrupção é dor. Se a via retorna para a sua essência mesma, a retirada é prazer para todos. A via da corrupção e da reparação remete às espécies de dor e prazer, originadas das afecçóes corporais. Mas, reside na alma mesma, 
por intermédio da antecipação das afecçóes, a esperança prazerosa e confiante e a aflição temerosa e dolorosa, havendo outra espécie de prazer e dor, nascida por antecipação na própria alma, princípio autárquico e intelectivo, separada do corpo. Os prazeres e as dores se originam previamente na natureza da própria alma autônoma.

De acordo com Gadamer (GADAMER, 1996, p. 228), Sócrates propóe constituir, pelo método de divisão por formas, a gênese efetiva dos prazeres. Por intermédio da análise das espécies de prazer, rejeita-se a compreendê-los numa totalidade homogênea e indiferenciada, porque há prazeres desejados e indesejados, considerando-os pela necessidade em suas formas específicas, podendo ou não receber a natureza discricionária do Bem. É preciso proceder pelo método dieirético para se compreender a natureza do prazer. Se a destruição é sofrimento físico e a reintegração prazer, não havendo nem corrupção nem reparação, nem harmonia, nem discórdia, haveria uma condição para os viventes, ausente de dor e prazer. Sócrates institui uma terceira disposiçáo, ao lado do estado agradável e do doloroso presente na vida intelectiva e sábia, concebida a mais divina de todas, julgando meritório o segundo prêmio para o intelecto. A segunda espécie de prazeres, proveniente da própria alma, é originada pela memória. Porém, a compreensão da memória depende do entendimento da sensação, pois " [...] a memória remete a uma percepção anterior, baseada em uma afecção corporal, uma impressão sensorial" (GADAMER, 1996, p. 234). Os prazeres corpóreos admitem o mais e o menos, prazer e dor infinitos, pertencendo ao gênero do ilimitado, enquanto os prazeres anímicos supóem a memória e a sensação. Das afecçóes do corpo, algumas se extinguem antes mesmo de atingirem a alma, enquanto outras, instaurando-se em ambos, provocam um abalo que os move singular e conjuntamente. As afecçóes que não penetram em ambos não são sentidas, porém as afecçóes que penetram conjuntamente em ambos são sentidas, imprimindo na alma do percipiente a memória do percebido. A compreensão do ignorado não indica uma gênese do esquecimento (léthes génesin), porque o esquecimento é a fuga, o êxodo da memória (mnémes éxodos) e a memória, se nem nasceu, tampouco existe (Fil.33e). Se a gênese do esquecimento é a perda da memória, não é plausível pensar a ausência de sensação, a apatia, como esquecimento, já que o ignorado não se apresenta à mente, não podendo conservar-se mnemonicamente, não podendo nos propiciar a reminiscência voluntária. A memória supôe a sensação, a união entre a alma e o corpo como condição de atividade e a reminiscência supóe a lembrança do outrora percebido. Quando a alma devém apática, por causa dos abalos do corpo, o 
que denominamos esquecimento, denomina-se ausência de sensação. Quando a alma e o corpo são reunidos em uma mesma sensaçáo, denominamos sensação ao movimento. Para Gadamer, "Sócrates demonstra que o prazer e a dor físicos participam igualmente da economia geral da alma” (GADAMER, 1996, p. 235). A conservação da sensação é denominada memória. Porém, a memória se diferencia da anamnese, uma vez que

\begin{abstract}
Platão opera uma distinção entre a memória que retém o conteúdo de uma percepção pretérita e a reminiscência que consiste em tornar presente algo que não existe mais, o conteúdo de uma antiga impressão ou a lembrança perdida de uma sensaçáo ou de um conhecimento pretéritos que a alma retoma na reminiscência. (GADAMER, 1996, p. 235).
\end{abstract}

Sócrates nomeia reminiscência ou anamnese e não memória quando a alma, tendo antes experimentado afecçóes por intermédio do corpo e tendoas retomado na memória sem o auxílio do corpo, rememora-as e quando, tendo perdido a memória quer de uma sensação quer de um aprendizado, relembra-os por si mesma a partir da reminiscência voluntária sem o auxílio da escrita. Se a memória é compreendida por um liame presencial com a sensação, a anamnese é uma qualidade pura da alma, a potencialidade de "[...] instaurar um liame com o não presente sem algum suporte material externo" (GADAMER, 1996, p. 236). A reminiscência é a permanência da lembrança afetiva na memória do ser, possibilitando-o restaurar a experiência do divino. "A alma aprende, reagrupando, por reminiscência, os fragmentos de seu saber pré-natal” (VLASTOS, 1994, p. 73). Assim, nem o prazer nem o desejo são autárquicos, pois dependem de sensaçôes corpóreas e das afecções psíquicas, conjuntamente, para serem percebidos e do recurso à atividade mnemônica e à reminiscência voluntária, efetuadas pela alma remêmora. Não há, assim, desejo corpóreo, porque o esforço de todo vivente tende sempre para a afecção contrária àquela percebida no corpo. $\mathrm{O}$ apetite, guiando-se para as afecçóes contrárias àquelas atualmente sentidas, evidencia que há uma memória das afecçóes contrárias presentes no ser. $\mathrm{O}$ apetite, o desejo e o princípio de todo vivente (tèn hormèn kaì epithymían kaì tèn archèn toû zôou pantòs) pertencem conjuntamente à alma (Fil. 35d). Se o prazer é uma afecção psíquica e não corpórea podemos inferir que, por causa de uma dolorosa afecção, lembra-se de prazeres que, surgindo, fariam cessar o sofrimento, mas não preencheriam ainda uma sensação agradável. Sócrates conjectura pelas duplas afecçóes que pode haver prazeres e dores verdadeiros ou falsos, do mesmo modo que podem existir opinióes e temores verdadeiros ou falsos ou alguns verdadeiros e outros 
falsos. Se o opinar e o aprazer são semelhantes e se o prazer é unicamente verdadeiro, por que há opiniáo verdadeira ou falsa? Que sobrevenha à opinião o falso ou o verdadeiro e que surja por intermédio deles não meramente opinião, mas de cada um uma qualidade, é preciso examinar, pois instituindo que tanto os prazeres quanto as dores têm qualidades, sendo grandes ou pequenos, fortes ou fracos, se lhes sobrevier o vício, a opiniáo devém viciosa ou o prazer vicioso. Se lhes sobrevier a retidão, julgamos haver a opinião reta ou o prazer reto (Fil. 37d). Se há uma suposição enganosa (hamartanómenon tò doxazómenon), é preciso homologar que a opinião, enganando-se, não supóe retamente. A opiniáo, por sua própria natureza, é intermediária entre o ser e o não ser, entre o verdadeiro e o falso, entre a ignorância e o conhecimento. Se a dor ou o prazer, enganando-se acerca do que sofre ou se apraz, carreia o falso juízo, não há nem a retidão nem a utilidade. $\mathrm{O}$ prazer parece frequentemente surgir em nós, diz Sócrates, não acompanhado de uma reta opinião (metà dóxes orthês), contudo de uma falsa opiniāo (Fil. 37e).

Sócrates indaga se não há real diferença entre o prazer acompanhado de reta opiniāo e de ciência (he metà dóxes te orthês kaì met'epistémes hedonè) daquele que surge frequentemente em nós acompanhado do falso e da ignorância (metà toû pseúdous kai agnoías) (Fil. 38a), evidenciando que opinião, prazer e dor, tanto os falsos quanto os verdadeiros, surgem a partir da memória e da sensação ( $e k$ mnémes te kai aisthéseos) (Fil. 38b) A nossa alma assemelha-se a um livro, porque a memória, reunindo-se com a sensação e com as afecçôes originárias, parece escrever nas almas discursos (gráphein en taîs psychaîs lógous). Quando uma afecção escreve coisas verdadeiras, resulta-nos, a partir dela, opinião verdadeira (dóxa alethès) e discursos verdadeiros (lógoi aletheîs). Todavia, quando o escrevente (grammateìs), existindo em nós, escreve-nos o falso, o resultado seria o contrário das opiniōes verdadeiras (Fil. 39a). Não há a apreciação do caráter deletério da escrita, mas o reconhecimento de que as paixôes podem imprimir na alma do ser discursos verdadeiros ou falsos, dependendo do gênero produtor de discursos que as suscitam, podendo ser o filósofo, os poetas trágico e cômico, o retor e o sofista. Sócrates, expondo o surgimento das opiniōes falsas, emprega a razão gráfica (BRISSON, p. 1990) para esclarecê-las, ensejando a compreensão de que outro produtor poderia ao mesmo tempo agir em nossas almas, como, por exemplo, o pintor (zográphon), que, depois do gramatista (tòn grammatistèn), desenha na alma as imagens dos discursos (tôn legoménon eikónas). Quando os objetos de opinião e os discursos advenientes são separados da visão ou de alguma outra sensação (tinos álles aisthéseos), observar-se-iam as imagens do que foi opinado e do que foi dito (Fil. 39b). As imagens das opinióes e dos discursos 
verdadeiros (hai tôn alethôn doxôn kaì lógon eikónes) são verdadeiras, enquanto as imagens das opinióes e dos discursos falsos são falsas (Fil. 39c). A idolopeica, arte por excelência produtora de imagens, pode manifestar tanto o lado reto da imagem, relativo ao conhecimento, à verdade e ao ser, evidenciado na idolopeica icástica, quanto também o seu lado sinistro, correlato à ignorância, ao falso e ao não ser, revelado na idolopeica fantástica. As referidas imagens decorrem, destarte, de afecçôes pretéritas, presentes e porvindouras. $\mathrm{O}$ dialético mimético escreve, por intermédio do poder de dialogar e de sua mimética, a idolopeica icástica, pensamentos, discursos e opinióes verdadeiros nas almas dos ouvintes, rejeitando os pensamentos, as opinióes e os discursos falsos, adversos à ordem do ser.

Os prazeres e as dores da alma surgem anteriormente aos prazeres e às dores corpóreos, proporcionando-nos, concernente ao tempo porvindouro, prazeres e dores antecipados, revelando-nos a preexistência da alma em face do corpo. As letras e as pinturas postas em nossas almas se referem ao pretérito, ao presente e ao porvir, porque o homem é pleno de múltiplas expectaçóes no que tange ao futuro. Assim, o que se denomina expectaçóes são discursos e as aparições, pinturas. A boa expectação é concedida a quem é amado pelos deuses, reiterando a relação entre o filósofo e o divino. As inscrições, para o homem justo e piedoso, são oferendas verdadeiras, enquanto para o homem injusto são oferendas falsas. Sócrates salienta que há nas almas dos homens falsos prazeres e falsas dores que imitam, conforme o risível, os verdadeiros, anuindo que tanto as opinióes quanto os prazeres são enganosos e deletérios quando se tornam falsos. As sensaçóes, as imagens impressas na alma, as opinióes, os prazeres serão verdadeiros se o homem participar do intelecto divino, se sua açấo for regida respeitando os prazeres bons. Os prazeres falsos existem e nascem múltiplos e frequentes. Se a alma é o desiderato dos estados contrários do corpo, o corpo é o permitidor de afecçóes dolorosas ou prazerosas. Os prazeres e as dores corpóreas, pertencentes ao gênero do ilimitado, originam-se e se presentificam ao mesmo tempo e conjuntamente com as suas sensaçóes contrárias e recíprocas. A corrupção da natureza pelas combinaçóes e dissoluçôes, crescimento e diminuição engendra dores e sofrimentos.

Porém, quando a sua natureza é reestabelecida, a sua restauração é prazer. A vida isenta de dor e de prazeres assemelha-se à vida divina, havendo três espécies de vida, a do prazer, a da dor ou a da completa ausência dessas afecçôes. Sócrates propóe a hipótese de que se se isentar da dor, não seria a mesma coisa que se aprazer. Seria a mais prazerosa de todas as coisas usufruir toda a vida sem dor? (Fil. 43d). Os êmulos de Filebo defendem que a vida 
feliz não reside na hegemonia do prazer, mas na isenção da dor. Segundo a reta razão, a vida média (mésos bíos) náo poderia devir nem prazerosa nem dolorosa, sendo ausente tanto de prazer quanto de dor. Os inimigos de Filebo são hábeis oradores (deinoùs legoménous) da natureza, afirmando não haver absolutamente prazeres, adivinhando a não hegemonia do prazer não por uma arte, mas por uma nobre natureza, repudiando, por esse prisma, o poder do prazer (tèn tês hedonês dýnamin), não o considerando sadio, de modo que a sua própria arte da seduçáo (tò epapogòn) não é, para eles, prazer, mas sim charlatanismo (tò goéteuma) (Fil. 44c) 3 $^{3}$ Os maiores prazeres e as maiores dores se originam a partir do vício da alma e do corpo e não da virtude (Fil. $45 \mathrm{e}$ ). Os prazeres misturados às dores nascem ora dos corpos e nos próprios corpos ou ora da própria alma e na alma, havendo dores misturadas a prazeres, originadas do corpo e da alma, cujo conjunto denominar-se-ia ora prazeres ora dores. Porém, cólera, temor, saudade, lamentação, amor, ciúme, inveja e congêneres constituem dores da própria alma (Fil. 47e). Não há a rejeição da esfera das sensaçóes, mas o reconhecimento de revelar a etiologia tanto dos prazeres quanto das dores. O liame de inter-relação entre alma e corpo nos previne de uma concepção correlata a um suposto dualismo psicofisiológico. A crítica à tragédia e à comédia, artes poéticas imitativas dramáticas, revelarse-ia indissociável duma etiologia dos prazeres, porque emergem do discurso trágico e do discurso cômico a mescla indistinta entre o prazer e a dor.

As poesias trágicas propiciam-nos a mescla de prazer e dor, pois nos aprazemos devido aos lamentos. A fruição estética que a tragédia nos oferece se baseia em prazeres impuros, no amálgama entre prazer e dor. Seria também a nossa disposição de alma nas comédias uma mescla de dor e prazer? Sócrates mostra os estados de ânimo provocados nos amantes de espetáculo pela tragédia e pela comédia. A natureza precípua do risível é um vício, sendo diferenciada pelas riquezas, quando muitos supóem serem mais ricos que as suas próprias fortunas e, também, serem maiores e mais belos conforme o corpo do que realmente são. A terceira espécie se refere àqueles que supóem serem mais virtuosos do que são. O risível é discernido por uma espécie de

\footnotetext{
3 Para Mié, a tese dos inimigos de Filebo não corresponde àquela defendida por Platăo, repousada na evidência da vida mista de prazer e sabedoria, năo sendo capazes de contemplar no uso dos prazeres nenhuma forma de positividade. Cf. MIÉ (2004 [2]: 316): "Pero la verdadeira causa de esa tesis, que Platón aquí le hace combatir a Sócrates como la mera contracara de la posición hedonista, reside en la aversión a combinar génesis y ousía". Os ascetas, assim como os hedonistas, compartilhariam a incapacidade de conjugar dialeticamente gênese e essência, devir e ideia. A função do dialético é pensar, portanto, a mistura ou comunidade entre gêneros aparentemente diferentes, remetendo à questâo da gigantomaquia manifesta no Sofista, que opunha aos partidários da incorporeidade os defensores da corporalidade.
} 
desmesura que abala o reto julgamento (Fil. 49a), pertencendo ao gênero do ilimitado. A apresentação da natureza do risível e de suas espécies permite a Sócrates expor o afastamento entre o filósofo e os falsos saberes, dirimindo a opiniáo comum de que o risível seria apreciado no filósofo, distante dos interesses vulgares. Sócrates defende que a ignorância é réproba e vil para os vigorosos, visto que a nocividade lhe é congenitamente própria e também a suas imagens, enquanto a debilidade de caráter pertence à ordem e à natureza das coisas risíveis, devendo ser afastada da reta educação. Quando rimos dos ridículos de nossos amigos, o raciocínio nos mostra que, mesclando o prazer à inveja, misturamos o prazer à dor. Nos lamentos, nas tragédias e nas comédias, não apenas nos dramas, mas em toda tragédia e comédia da vida e em outras miríades, as dores misturam-se, ao mesmo tempo, aos prazeres, resultando na alma tanto do espectador quanto do paciente as emoçóes ilimitadas.

O componente deletério da tragédia e da comédia se efetua pela promoção dos prazeres impuros, produzindo na alma poderes contrários à reta natureza humana. A tragédia e comédia, à medida que são imitaçôes de simulacros, distanciam o espectador dos prazeres puros e bons, imergindo-o em uma pluralidade de aparências, nas quais se misturam os poderes nefandos das açóes humanas. Os poetas trágico e cômico, afastados triplamente do real, imitam os atos humanos na ignomía e no risível. O imitador aparente mistura as opiniōes falsas aos prazeres impuros. A crítica platônica à poesia trágica revela a disposição natural do tragediógrafo para a imitação não do caráter temperante, mas do caráter irascível da alma, pela qual assegura a simpatia da multidáo, misturando, em sua composiçáo, o prazer à dor. A poesia, privilegiando o ethos colérico, nutre a parte ignominiosa e corrompe a parte racional da alma. O poeta imitador instaura na alma de cada ser um mau regime, propiciando a dissensão dos poderes anímicos. A invectiva platônica contra a poesia repousa na inadequação da imitação poética à eunomia política. A poesia imitativa homérica propicia nos alimentarmos de prazeres impuros e ilimitados, pois nos lamentamos com os infortúnios de seus heróis, não nutrindo o caráter racional e temperante da alma. $\mathrm{O}$ melhor elemento de nossa natureza, não sendo corretamente educado pela razão e pelo costume, relaxa a guarda perante as lamentaçóes dos heróis, não considerando deletério, como espectador, afligir-se com os sofrimentos do personagem. O poeta trágico provoca pela simpatia com o lamento heroico a fraqueza de alma, afastandonos da adequação à vida justa, mista e feliz, do prazer puro e definido. A condenação platônica dos prazeres e opinióes miscíveis e falsos evidencia a sua crítica às poesias trágica e cômica, triplamente afastadas, pela mímesis, 
do real. O poeta cômico, produzindo o risível, apraz com suas imitaçóes a pusilanimidade de alma. A piedade trágica e a bufonaria cômica provocam no espectador emoçôes patéticas, porque se originam tanto na comiseração, suscitada pela piedade trágica, quanto na derrisão, suscitada pela bufonaria cômica, prazeres e dores falsos e também miscíveis, remissivos não ao gênero do limite, mas ao gênero do ilimitado. A vida hedonista não pode, assim, ser sujeitada à natureza miscível e ilimitada das poesias trágica e cômica.

Por que entendemos a mistura, em particular na comédia? Sócrates considera mais fácil apresentar a fusão nos temores, nos amores e congêneres. A crítica socrática da tragédia, comédia e de outros dramas se realiza pela miscibilidade entre prazeres e dores. A apreciação das muitas espécies de prazer propicia a Sócrates evidenciar o afastamento do prazer do filósofo dos outros gêneros hedonistas, presentes em discursos alheios à filosofia, como a comédia, a retórica e a sofística. A eunomia política não pode admitir a Musa voluptuosa, mas apenas os hinos em louvor aos deuses e o encômio dos homens bons. Qual prazer distante dos prazeres impuros é o prazer verdadeiro? O puro, imisturável e suficiente, ou o extremo, numeroso e grande? Sócrates enfatiza que certos homens engenhosos se empenham em nos revelar que o prazer é sempre gênese (aei génesis estin) e não é absolutamente essência (ousía dè ouk ésti tò parápan) (Fil. 53c). Há dois gêneros de seres, o que é em si e por si (tò mèn autò kath'autó) e o que tende para outro (tò d'aei ephiémenon állou) (Fil. 53d). O primeiro é, por natureza, sempre o mais venerável, sendo autônomo e autárquico, enquanto o outro é inferior àquele, sendo-lhe subordinado. Sócrates busca entendê-los pelo impulso erótico, pois contemplamos nesse, ao mesmo tempo, jovens amados belos e bons e seus amantes viris, de modo que esta díade é símile àquela e a todas proferidas, porque se entendem os seres ou em vista sempre de um fim ( $t \grave{o}$ héneká tou) ou o próprio fim desejado (tò d'hoû chárin) (Fil. 53e).

Sócrates emprega a imagem sensível da afecção erótica para evidenciar a relação entre gênese e essência. Se pensarmos na díade gênese e essência, qual seria em vista do fim e qual seria o próprio fim? A gênese visa à essência (tèn génesin ousías héneka) ou a essência visa à gênese (tèn ousían genéseos héneka) (Fil. 54a)? Sócrates aquiesce que todos os medicamentos, todos os instrumentos e todo material são oferecidos visando à gênese e cada gênese determinada origina-se visando à outra essência determinada assim como a gênese em sua completude devém visando à essência em sua completude. Se o prazer é gênese, ele necessariamente nasce visando a certa essência (Fil. 54c). Se o prazer, portanto, não é essência, sendo gênese, pertence à outra parcela 
que a parcela do Bem (tèn tôu agathoû moîran) (Fil. 54d), não podendo ser confundido, pelo método da divisão, como uma parte do Bem. Se o prazer é gênese e a geração aceita seu contrário, a corrupção, é forçoso reconhecê-lo também por meio da corrupção, podendo promover tanto a harmonia quanto o dissenso. Se o Bem não é nem prazer nem seu oposto, a dor, nem gênese nem corrupção, não sendo ilimitado, propóe-se uma terceira vida, a do conhecer, considerada a mais pura possível. Não seria ilógico não admitir o bom e o belo nem em corpos nem em muitos outros, exceto na alma e nela unicamente o prazer? A coragem, a temperança, o intelecto e tantos outros bens não seriam atribuídos à alma? Não é lícito realizar uma análise do prazer, sem privilegiar o intelecto e a ciência (noû kai epistémes), sendo preciso observar o que há por natureza neles de mais puro, empregando, para a mescla comum (tèn krâsin tèn koinèn), de suas partes mais verdadeiras, misturadas às do prazer (Fil. 55c). Sócrates supóe que os aprendizados da ciência se referem, de um lado, à formação e à educação e, de outro, à produção, anuindo que umas contêm mais ciência do que as outras, sendo preciso reconhecer que umas são mais puras enquanto as outras mais impuras. Assim, é necessário discerni-las, separando, em cada uma daquelas, as ciências hegemônicas. Se separássemos de todas as artes a aritmética, a metrética e estática, o que permaneceria de cada uma delas seria insignificante. Resta-nos, afirma Sócrates, apenas conjecturar, exercendo os sentidos mediante a empiria e por uma prática rotineira, utilizando-se dos poderes da arte do conjecturar, que os muitos denominam artes, mas cuja eficácia advém do exercício fatigante. A aulética é plena disso, pois ajusta a consonância não pela medida, mas pela empiria, assim como a música em sua totalidade, que procura a medida de cada corda pela conjectura, sendo permeada pela náo clareza e pelo mínimo de firmeza, tal como a medicina, a agricultura, o estrategismo e a arte do timoneiro. Porém, a arte do carpinteiro emprega mais medidas e instrumentos, fornecendo maior rigor, sendo mais arte do que a maioria das ciências. Sócrates separa as mencionadas artes em duas: há aquelas que acompanham a música, apresentando menor exatidão em suas obras, e há aquelas que se aproximam da arte do carpinteiro, tendo maior exatidão, utilizando-se de régua e compasso. A aritmética também pode ser separada em duas: há a aritmética dos muitos e há a dos filósofos, uma vez que os muitos calculam unidades desiguais, como duas armadas, dois bois, magnitudes ínfimas e grandes, não superando a empiria e a prática rotineira, enquanto os filósofos empregam a geometria filosófica, procedendo ao cálculo independentemente da prática empírica. A esfera dianoética nos remete ao conhecimento realizado por intermédio do intelecto, que depende 
do emprego de figuras, propiciando a superação da simples empiria. As artes se diferenciam ou por sua maior clareza ou por sua maior obscuridade. As artes aplicadas ao impulso dos verdadeiros filósofos são prodigiosas em exatidão e em verdade, distinguindo-se de todas as outras em medida e número, em qualidade e quantidade. $\mathrm{O}$ poder dialético (he tồ dialégesthai dýnamis) se refere ao ser, ao real e ao sempre idêntico por natureza e de modo absoluto (tò òn kaì tò óntos kaì tò katà tautòn aeì pephykòs pántos), sendo o conhecimento o mais verdadeiro (Fil. 58a). A arte do persuadir subordina todas as coisas de acordo com o consentimento e não pela força, por anuência e não por violência, sendo de todas as artes a melhor. $\mathrm{O}$ poder natural de nossa alma é desejante do verdadeiro, e tendo-o como fim, apropria-se do puro do intelecto e da sabedoria. Não há nenhuma outra ciência ou arte que esteja além dela e tampouco que se aproximasse mais do que ela mesma do verdadeiro. As muitas artes, opostas à ciência dialética, adotam opinióes, dirigindo-se para o exame da natureza, do devir pretérito, presente e futuro, não se preocupando com o que sempre permanece idêntico, com o imutável, sobre as coisas que não possuem nenhuma estabilidade, não há nem intelecto nem alguma ciência que tivesse acerca delas o mais verdadeiro. $\mathrm{O}$ intelecto e a sabedoria são os nomes mais veneráveis atribuídos àquelas artes que remanescem sempre idênticas a si mesmas. A opinião existe em vista da gênese e o intelecto em vista da essência. Porém, para Filebo, o prazer é a justa meta de todos os viventes e o seu bem universal, reiterando sua ética hedonista para uma vida mista feliz, de sorte que bom e prazeroso seriam dois nomes que se aplicam a uma mesma e única natureza correlata ao prazer.

Sócrates rejeita essa pretensa unidade, porque, para ele, o bom e o prazeroso têm naturezas diferentes, em que a sabedoria participa mais do lote do bem do que o prazer (Fil. 60b). A vida feliz e comum seria a mescla recíproca de prazer e sabedoria, sendo necessário entendermos, mediante a razão, o prazer imiscível à sabedoria e, do mesmo modo, essa não misturada ao prazer. A dicotomia entre prazer e sabedoria efetua-se meramente por meio do pensamento, pois memória, sabedoria, ciência e opinião verdadeira (mnémen kaì phrónesin kaì epistémen kaì alethê dóxan) não subsistiriam sem o prazer nem este sem aqueles. A natureza do Bem se diferencia tanto de uma vida puramente hedonista quanto de uma vida puramente sábia, porque ambos, prazer e sabedoria, não coincidem com o perfeito, o universalmente elegível e o bem absoluto (tó téleon kai pâsin hairetòn kaì tò pantápasin agathòn) (Fil. 61a). O filósofo rejeita, por conseguinte, tanto a ética absolutamente hedonista quanto uma ética absolutamente sábia e mnemônica. A morada do bem seria 
a vida mista, comum e feliz e reconhecê-la seria sua maior expectação. A demiurgia da vida feliz necessita ser efetuada mediante a mescla correta entre o prazer e sabedoria, pois há uma ciência mais verdadeira do que a outra e uma arte mais exata do que outras artes. A ciência mais verdadeira seria aquela que se dirige para o ingênito, incorruto e sempiterno. Os portadores de libaçôes, Sócrates e Protarco, misturariam a fonte prazerosa de mel à água austera e saudável da sabedoria. A vida mais desejável nasceria da mescla suficiente dessas seçóes as mais verdadeiras. A vida amada não poderia surgir de um único gênero, porque um gênero único, isolado e imiscível não seria nem possível nem proveitoso. Mas, de todos os gêneros, o melhor é aquele que, habitando conjuntamente com a sabedoria, conhece todos os outros e cada espécie de prazer perfeitamente e possível. Se misturarmos indistintamente toda espécie de prazer a toda espécie de sabedoria, não há nenhuma exatidão em obter a mistura adequada, pois as diferentes espécies não têm o mesmo grau de verdade no que diz respeito ao gênero (GADAMER, 1996, p. 303). Os prazeres verdadeiros e puros, sujeitados à natureza limitada da sabedoria, são considerados quase nossos parentes, acompanhados da saúde, da temperança e de todos aqueles que seguem a virtude como se ela fosse uma divindade. Os prazeres que acompanham a intemperança e outros males, subordinados à hegemonia do ilimitado, nos trazem muita desrazão, se porventura forem misturados ao intelecto. Se quisermos contemplar o mais belo compósito e a mescla mais estranha às facçôes, então é preciso predizer o que é por natureza o bem nos homens e no todo e sua ideia. Sócrates refere-se à predição, por causa do caráter divino da ideia do Bem, cujo poder é congênere ao inteligível. Os prazeres bons, não viciosos, júbilo, sensaçóes agradáveis, memória, sabedoria, intelecto, opiniáo verdadeira, são constituintes à observação da ideia do Bem.

Qual é, nessa mistura, o mais venerável e ao mesmo tempo a causa por excelência que supomos originar para todos os homens uma requerida condição plena de benevolência? Todo compósito, qualquer que seja a forma de sua composição, se privado de medida e proporção, os ingredientes e ele próprio necessariamente se corrompem. A mistura adequada, considerada uma ordem incorpórea, regendo belamente um corpo animado, necessita dos critérios de medida e de proporção. Se não há mescla comum, mas um amálgama indistinto, origina-se para seus possuidores um verdadeiro infortúnio. A bela ordem incorpórea, regente dos corpos animados "[...] manifesta a essência do Bem por intermédio de suas três propriedades constitutivas, proporção, verdade e beleza" (GADAMER, 1996, p. 308). A vida mista compósita, para ser elegível e boa, precisa ser a mais congênere e mais semelhante à ideia do 
Bem. A ideia do Bem, conquanto mantenha, no dizer de Gadamer, um halo de imprecisão, é meramente contemplada pelos seus rebentos, o belo, o justo e o verdadeiro. O poder do Bem (he toû agathoû dýnamis) refugiou-se, segundo

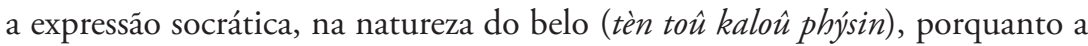
medida e a proporção, noçóes precisamente dianoéticas, fazem nascer por toda parte o belo e a virtude ${ }^{4}$, misturando-se a eles nessa mescla a verdade. Qual deles, o prazer ou sabedoria, julgamos nos homens e nos deuses ser o mais venerável e o mais congênere ao melhor? Se o prazer é gênese, tende para um fim outro do que ele próprio, que seria uma essência. $O$ prazer não é nem suficiente em si nem perfeito, não sendo o mais congênere à verdade. $O$ intelecto é idêntico à verdade, o mais semelhante e o mais verdadeiro. $\mathrm{O}$ intelecto e a ciência são os mais proporcionados, ausentando-lhes qualquer desmesura. $\mathrm{O}$ intelecto participa mais do belo do que o gênero do prazer, porquanto jamais decerto alguém viu ou imaginou, ressalta Sócrates, quer em sono quer em vigília, que a sabedoria ou o intelecto pudessem devir ou ser viciosos. $O$ prazer náo seria nem o primeiro nem o segundo bem desejável, pois o primeiro é concedido à medida, ao mesurado, ao conforme e todos quantos lhes forem idênticos. O segundo bem desejável é atribuído à proporção, ao belo, ao perfeito, ao suficiente e todas da mesma linhagem. O terceiro bem seria o intelecto e a sabedoria. As ciências, as artes, as opinióes retas seriam o quarto desejável, por serem mais congêneres ao Bem que o prazer. O quinto seria, com efeito, os prazeres isentos de dor e aqueles outros prazeres considerados puros da alma.

Sócrates diz que Filebo defendeu ser o prazer o bem universal e absoluto. Porém, Sócrates defendeu ser o intelecto superior e melhor do que o prazer. Todavia, nem o prazer nem o intelecto são suficientes, faltando-lhes a autarquia e o poder do suficiente e perfeito (Fil. 67a). No entanto, tendo se manifestado um terceiro, superou tanto um quanto o outro, tendo o intelecto mais parentesco e mais naturalidade com a forma do vencedor (tê tôे nikôntos idéa) (Fil. 67a). O intelecto é o mais congênere ao Bem, o supremo desejável. $\mathrm{O}$ prazer náo seria o quarto, mas o quinto na ordem dos valores, porque o Bem

\footnotetext{
${ }^{4}$ Para Dixsaut (DIXSAUT, 2000, p. 257), os três critérios fundamentais da forma do Bem, medida, proporção, beleza, não são três espécies de um mesmo gênero correlato ao $\mathrm{Bem}$, mas três efeitos inseparáveis de seu poder que se interdependem. Segundo Mié (2004[2], p. 321), os conceitos de virtude e beleza definem a aparição e concreção do bem na estrutura da facticidade humana. Pela correlação entre o bem e a vida boa, Platâo pôe em relevo a orientação racional necessária à prática ética. Cf. MIÉ (2004 [2], p. 322): "Similarmente a lo que sucede en la República, en el Filebo se demarca la diménsion de un más allá de las entidades, de una naturaliza que es la possibilidade articulada en toda realidad ( he tôे agathồ dýnamis, Phlb. 64 e), una potencia que se efectiviza en distintas formas y constitue la forma misma de la realidad".
} 
é o primeiro. Não obstante, enfatiza Sócrates, todos os bois, cavalos e todas as feras conjuntamente aspirem ao regozijar, os muitos julgam, acreditando neles, tal como os adivinhos nos pássaros, serem os prazeres os mais poderosos para o bem viver, considerando os amores das feras testemunhos mais autorizados do que os amores dos discursos vaticinados pela Musa filosófica (Fil. 67b). A vida mista nutrida na alma filósofa adquire a felicidade, pois seu compósito é mesclado pelos bens desejáveis. A isonomia mútua da mistura assegura a vida feliz e comum, haja vista os principais bens serem a medida e a proporção. Se forem ausentes, a desmesura carreia corrupção e dor, enquanto, se presentes, gênese e prazer. A virtude, o verdadeiro, o intelecto, são frutos da retidão e da simetria. Reiterando, é preciso, para o inquérito socrático, fazer a justa eleição dos prazeres e conhecimentos mais puros, não miscíveis, a fim de instituir a autarquia e autonomia da vida feliz, a qual é proveniente da mescla correta, de uma mistura cujos constituintes se combinam retamente e cuja superveniência de um componente qualquer náo prejudica a eleição de outro. A dialética é a arte que evidencia a reta mistura entre o prazer e a sabedoria, entre a natureza indefinida e ilimitada e outra definida e limitada. A dialética, enquanto poder de ascese anímica dos prazeres e opinióes para o vestíbulo do Bem, é a única, oposta ao poder antilógico, que se eleva para a vida feliz, porquanto é congênere ao poder do perfeito e suficiente. O dialético opóe-se ao erístico e aos outros produtores de imagens, como o poeta, o retor e o sofista, pois, pela divisão das espécies de prazer, proporcionada pela ciência dialética, pode, com efeito, separar prazeres verdadeiros dos miscíveis, impuros. Mediante o método de divisão, separando os semelhantes dos dessemelhantes, o primeiro prêmio foi atribuído à ideia e natureza do Bem, considerada o princípio náo hipotético.

A forma do Bem, por causa de sua natureza supraessencial, tanto em estima quanto em poder, deve ser apreendida pela atividade noética, congênere à razão divina pura e imiscida. A forma do Bem, porquanto ideia mais venerada e sublime, é própria da sabedoria divina. A razão humana pode apenas apreendê-la pela esfera dianoética, na medida em que essa supraessencialidade se refugia na natureza sublime do Belo. Se o poder do Bem se refugiou na natureza do Belo, cuja contemplação sensível nos propicia a anamnese da ideia do Belo em si, a beleza é entendida dianoeticamente pelo liame com o verdadeiro, com a simetria e com a proporção. Os prazeres e dores ilimitados surgem do deslumbramento efetuado pela retórica e sofística, pelas poesias trágica e cômica, épica e lírica. Os prazeres puros não misturados nascem da causa da mescla comum entre vida sábia e vida hedonista. A alma filósofa ascende ao súpero, lugar supraceleste, onde moram o belo, a proporção, o 
perfeito, contemplados pelo poder dialético. Os gêneros supremos da vida mista e comum são o limite, o ilimitado, a mistura e a causa da mistura, discernidas pelo poder dialético, refutando a pluralidade indeterminada. A vida feliz se realiza pela presença do bom nume. A vida numinosa é aduzida de princípios dianoéticos, o limite, o ilimitado e a mistura resultante e, também, do princípio noético correlato à causa da mistura. A vida numinosa se revela ao filósofo por causa de sua natureza teófila, afastada dos meros interesses vulgares hegemônicos nos tribunais e nas assembleias populares. A ciência dialética não prescinde das três primeiras modalidades do conhecimento, já que tanto se privilegia a reta imagem do belo e a opiniáo verdadeira, quanto a capacidade dianoética de apreensão da medida e proporção presentes na bela ordem incorpórea. A forma do Bem, por ser congenérica à sabedoria divina, pode ser apenas reconhecida pela possessão numinosa, compreendendo os princípios dianoéticos atestados nas mútuas relaçôes entre as formas singulares. A dialética filosófica entende, em primeiro lugar, a relação recíproca entre o sensível e o inteligível em termos de participação ou semelhança e, em segundo, a relação mútua, de um lado, apenas entre os sensíveis e, de outro, apenas entre os inteligíveis em termos de comunidade ou mistura. A relação de participação ou semelhança entre a imagem sensível e sua ideia inteligível é homóloga à relação de participação ou semelhança entre o mortal visível e o seu deus invisível, assim como a comunidade dos gêneros supremos evidencia a comunidade dos deuses imortais.

A proporção, beleza e verdade seriam manifestaçóes da ideia e do poder supraessencial do Bem, critérios dianoéticos por meio dos quais se reconheceria o que é, por natureza, bom, reiterando o esquema tanto ontológico quanto genealógico que aquiesce ser o Bem o pai e a causa de todos os entes, considerado (i) princípio de cognoscibilidade, (ii) princípio da verdade e (iii) princípio da existência. A medida, par nocional da proporção, e a simetria permitiriam ao sensível subtrair-se à hegemonia metabólica do devir, mantendo a comunidade com a essência, haja vista que a gênese corruta deve ter, como fim superno, se respeitar o intelecto, a essência incorruta.

A magnífica inovação do texto platônico reside em sua iniludível habilidade para incorporar em seus quadros de pensamento, em suas categorias mentais, as formulaçôes de seus predecessores, e de forma precípua, o eleatismo, interpretando-os pelo prisma de sua ontologia. A pretensão de circunscrever o diálogo sobre a vida mista feliz a uma suposta teoria esoterista, refletindo as preocupaçóes matematísticas do platonismo tardio e cuja fonte 
primária repousaria no hipotético testamento ágrafo, defendendo a redução do amplexo fenomênico a dois princípios relativos ao um e à díada indefinida do grande e pequeno, esmaece a compreensão de tópicos reiterativos da obra platônica e manifestos ao longo desta tese correlatos à afirmação de que a gênese do esquecimento é o êxodo da memória, ao reconhecimento de que as artes dianoéticas são disciplinas propedêuticas à apreensão pelo raciocínio da medida, do justo e do belo, à apologia da expectaçáo humana relacionada à ideia e poder supraessenciais do Bem, à anuência de que a não manifestação do ser carreia a imaginação, o discurso e a opinião falsos. Por esses dados, as inferências realizadas na diatribe sobre o prazer revelam-se fidedignas ao escopo do platonismo conspícuo, pois ressaltam a prevalência da sabedoria e do saber numinoso para a reta aquisição da vida compósita feliz e o posicionamento do filósofo dialético em face de certos produtores de discurso que descuram da realidade fenomênica, fixando-se apenas no âmbito da prestidigitação e das imagens fantásticas dissimulatórias. Se não se produz a mescla correta entre as melhores partes dos prazeres e dos conhecimentos, a mistura imperfeita acarretaria na vida humana a dependência dos prazeres impuros e dos falsos conhecimentos, frequentemente praticados nas assembleias, nos tribunais e no âmbito público. O filósofo dialético tem a ciência necessária para apreender as múltiplas relaçóes efetuadas tanto entre as imagens e seus paradigmas quanto entre as próprias ideias, assim como o poeta tinha o venerando dom náo apenas para reconhecer a participação dos mortais na divindade, mas também para revelar a suprema comunidade dos deuses. A dialética filosófica náo pode ser confinada nos limites de um saber metafísico, cindindo os âmbitos dos reinos sensível e inteligível e separado da própria história evolutiva da esfera política presente na pólis ateniense clássica, haja vista que se apresenta como hermenêutica própria das categorias arcaicas longamente sedimentadas no mundo grego pré-platônico.

A invenção platônica da dialética deriva da necessidade de entender a relação entre o um e sua consequente dispersão fenomênica. A escolha, com efeito, do prazer como tema precípuo da diatribe entre Sócrates, Protarco e Filebo permite a Platão reconstituir as linhas fundamentais de seu pensamento, correlatas (i) à harmonia complexa entre o um e a multiplicidade fenomenal, (ii) ao reconhecimento da memória como critério do conhecimento, porquanto a gênese do olvido é a fuga mnêmica, (iii) à asserção da essência como fim supremo da geração e da ciência como finalidade superna da reta opinião, (iv) à comprovação da proeminência das artes ditas dianoéticas assegurando respeito e louvor à ideia e poder supraessencial do Bem, (v) ao encômio da 
morada divina do Bem, interdita à natureza mortal, reiterando, destarte, a hierarquia ontológica entre a gênese sensível e a essência inteligível, (vi) à analogia da dialética às artes gramatical e musical, pensadas como tessituras de elementos indivisíveis, (vii) à apreciação do caráter ou nefando ou venerando da escrita. Respeitados esses critérios, anuídos no processo da exposição, circunscreve-se, para o discurso filosófico, a questáo ética da vida feliz pela determinação dos gêneros do limite, do ilimitado, da mistura e da causa da mistura. Se, no inquérito sobre o gênero sofístico, diferem-se os gêneros supremos do ser, do mesmo e do outro, do movimento e do repouso, se, no discurso verossímil sobre a gênese do cosmo, aferem-se os gêneros da Forma, do fenômeno, do receptáculo e do demiurgo, náo podemos aduzir perfeita semelhança entre esses gêneros e aqueles discernidos no escrutínio da vida média feliz, pois o pensamento filosófico platônico não se constitui como um sistema. Se é pertinente associarmos às Formas o limite, dado ser o intelecto e a ciência naturezas definidas, se é lícito relacionarmos aos fenômenos o ilimitado, porque há múltiplos prazeres, se se observa uma possível homologia entre a causa da mistura, o intelecto, e a atividade demiúrgica, não podemos associar ao receptáculo a mistura entre limite e ilimitado, a mescla entre a vida hedonista e a vida sábia.

A aplicação de categorias epistêmicas modernas para o entendimento do diálogo nos induziria a atestar uma lacuna conceitual referente à ideia e ao poder do Bem. Porém, essa leitura é apenas lícita por uma interpretação extrínseca do diálogo, a qual presume haver um hipotético testamento ágrafo filosoficamente superior aos textos dos Diálogos. A teoria esoterista, defendendo um presumível testemunho não escrito, associa o limite e o ilimitado respectivamente ao um, causa formal, e à díada indefinida do grande e pequeno, causa material, apoiando-se nas chamadas liçóes platônicas sobre o Bem. A redução dos constituintes necessários à vida ética feliz a componentes matematísticos exprime menos os pressupostos da dialética platônica do que os fundamentos da metafísica aristotélica, reiterados pela doxografia peripatética de Teofrasto e Alexandre de Afrodísia. O grande e o pequeno referem-se antes a exemplos que firmam a premência das ciências dianoéticas para o entendimento das estruturas ontológicas, não se reportando, porém, a uma ulterior essência ou natureza substrata, substrato ou suporte material das ideias número. A interpretação esoterista, fundamentada na dogmática não escrita, minimiza as formulaçóes platônicas relativas à ética e à política em proveito de um hipotético sistema apriorista de princípios correlatos aos princípios formal e material, ou seja, ao um e à díada indefinida do grande e do pequeno. A teoria dos dois princípios, 
defendida por tubinguenses como Konrad Gaiser e Hans Krämer, é, com efeito, iniludivelmente conexa à crítica metafísica aristotélica do pré-platonismo e do platonismo. Para Luc Brisson (BRISSON, 1995), em seu estudo sobre os pressupostos e consequências da leitura esoterista, a tarefa suprema de Platão é, antes, constituir um projeto ético-político conjunto às contemporâneas disposiçóes legislativas, pensando a ontologia e a epistemologia pela ética e política, fins que a corrente esoterista, registrada nas doutrinas não escritas, desconsidera, em favor dos testemunhos não escritos.

A hermenêutica do texto platônico permite, antes, ponderar sobre os limites do saber humano e evidenciar a consequente transposição de uma moralidade trágica para uma moralidade filosófica, de um discurso mitopoético para um discurso filosófico. A congeneridade entre a sublime sabedoria divina e o inspirado saber humano se efetua à medida que o filósofo manifesta, por um reto discurso, a tecedura da demiurgia divina, baseada na mútua comunidade dos gêneros e no entrelaçamento das formas inteligíveis. O discurso verdadeiro, efetuado pelo poder dialético, oposto ao poder antilógico e erístico, deve aparecer como a imagem sensível da harmonia entre os entes invisíveis, intangíveis e incorpóreos. A dialética se apresenta como esse discurso vivo e animado, considerado logografia filosófica e suprema psicagogia, que, adverso aos gêneros miméticos retórico, poético e sofístico, portanto, à má logografia, à poesia e à doxosofia, imita sábia e verdadeiramente o ser e sua inteligibilidade. A crítica platônica à poesia, por exemplo, se reporta a uma invectiva de natureza não estética, mas ontológica, pois não se trata de desqualificá-la como obra literária, mas de expor seus efeitos na alma, centrados em uma fenomenologia das paixôes. A concepção deontológica da vida mista feliz se origina da compreensão ontológica da mescla comum entre o limite e o ilimitado. A observância da reta comunidade, na qual o ilimitado é subordinado à hegemonia do limite, permite, para o filósofo, o domínio das paixôes, recrudescidas pela tragédia e pela comédia, promotoras das ilimitadas afecçôes respectivas de comiseração e derrisão. A crítica platônica à arte poética imitativa nasceria, por esse prisma, do reconhecimento duma fenomenologia das paixôes, do acurado estudo das manifestaçóes afetivas na alma do ser. Respeitadas essas consideraçóes, poder-se-ia afirmar que o opróbrio da imitação se relacionaria, para Platão, às possíveis consequências deletérias produzidas na esfera pública pelos gêneros produtores de imagens falsas. A dialética filosófica almeja, pela reta linguagem, realizar o liame entre fenomenologia, ontologia e deontologia, pelo qual o discurso verdadeiro 
pode manifestar retamente a opinião e a imaginação verdadeiras, enquanto o discurso falso pode revelar sinistramente a opiniấo e a imaginação falsas.

RACHID, Rodolfo. The incorporeal order in Plato's Philebus. Trans/Form/Ação, Marília, v. 35, n. 2, p. 3-30, Maio/Ago., 2012.

\begin{abstract}
In this paper, I intend to analyze how Plato's Philebus takes up some specific topics of Platonic dialectic and employs them to understand how the cognitive soul can be affected by false pleasures, false opinions, and false images. This study aims to criticize certain modern readings of Platonism, chiefly esoteric theory based on Plato's unwritten doctrine, which stipulate a revision of the Platonic theory of forms and defend the emergence of a new ontology explained by two principles, the One and the unlimited Dyad of great and small, conceived both as formal principle and material principle.
\end{abstract}

KEYWORDS: Dialectic. Ontology. Idea of good. Eudaimonistic ethic. False pleasures. Wise imitation.

\title{
REFERÊNCIAS
}

BRISSON, Luc. Platon, Pythagore et les Pythagoriciens. In: DIXSAUT, Monique (Org.). Platon, Source des Présocratiques: Exploration. Paris: Jean Vrin, 2002.

. Présupposés et conséquences d'une interprétation ésotériste de Platon. In :Méthexis VI, 1995.

CASERTANO, Giovanni. Parménide, Platon et la Vérité. In: DIXSAUT, Monique (Org.). Platon, Source des Présocratiques: Exploration. Paris: Jean Vrin, 2002.

CHERNISS, Harold. L'économie philosophique de la théorie des idées. Trad. J.F. Pradeau. In: PRADEAU, Jean-François (Org.). Platon: les formes intelligibles. Paris: PUF, 2004.

DIXSAUT, Monique. Le naturel Philosophe. Paris: Jean Vrin, 1994.

. Métamorphoses de la dialectique dans les Dialogues de Platon. Paris: Jean Vrin,

2001.

. Platon et la Question de la Pensée. Paris: Jean Vrin, 2000.

. Platon. Le Désir de Comprendre. Paris: Jean Vrin, 2003.

GADAMER, Hans-George. L'Éthique dialectique de Platon. Paris: Actes Sud, 1996.

. Lidée du Bien comme Enjeu platonico-aristotélicien. Paris: Jean Vrin, 1994.

HUFFMAN, Carl. Limite et Illimité chez les premiers philosophes grecs. In: DIXSAUT, Monique (Org.). La Fêlure du Plaisir: Études sur le Philebe de Platon, 2. Contexts. Paris:Jean Vrin,1999. 
KRÄMER, Hans. Platone e i fondamenti della metafisica. Saggio sulla teoria dei principi e sulle dottrine non scritte di Platone. Milano: Vita \& Pensiero, 1982.

MIÉ, Fabian. Lenguaje, Conocimiento y Realidad en la Teoría de las Ideas de Platón. Investigaciones sobre los diálogos medios. Córdoba: Ed. del Copista: 2004.

. Dialéctica, Predicación y Metafísica en Platón. Investigaciones sobre el Sofista y los Diálogos tardíos. Córdoba: Ediciones del Copista: 2004 [2].

PATER, Walter. Les Topiques d'Aristote et la dialectique platonicienne. Suisse: Editions St. Paul Fribourg, 1965.

PLATÃO. Philébe. Texte établi et traduit par Auguste Diès. Paris: Les Belles Lettres, 1993. Philébe. Traduction, introduction et notes par Jean François Pradeau. Paris: GF Flammarion, 1998.

VLASTOS, Gregory. Socrate. Ironie et Philosophie morale. Paris: Aubier, 1994.

Recebido em: 15.08 .2011

Aceito em: 10.10.2011 